\author{
Angela NOWAK ${ }^{1}$, Elżbieta MACIOSZEK ${ }^{2}$ \\ Opiekun naukowy: Elżbieta MACIOSZEK ${ }^{2}$ \\ DOI: https://doi.org/10.53052/9788366249851.06
}

\title{
INTERCHANGE NODES IN PASSENGER TRANSPORT - A CASE STUDY ON THE EXAMPLE OF THE CITY OF SOSNOWIEC (Poland)
}

\begin{abstract}
Summary: Accurate layout and design of interchange nodes in the city facilitates the use of various means of public transport, which in turn gives passengers the opportunity to reduce travel time and reduces the effort required to transfer between different means of transport. The article presents the characteristics of the infrastructure of interchange nodes in passenger transport on the example of the city of Sosnowiec (Poland).
\end{abstract}

Keywords: transfer junctions, transport, road transport.

\section{WEZZŁY PRZESIADKOWE W TRANSPORCIE PASAŻERSKIM - STUDIUM PRZYPADKU NA PRZYKŁADZIE MIASTA SOSNOWIEC (Poland)}

Streszczenie: Dokładne rozplanowanie i zaprojektowanie węzłów przesiadkowych w mieście ułatwia korzystanie z różnych środków publicznego transportu zbiorowego, co z kolei daje pasażerom możliwość zredukowania czasu podróży i zmniejsza wysiłek niezbędny do wykonania przesiadki pomiędzy rożnymi środkami transportu. W artykule została przedstawiona charakterystyka infrastruktury węzłów przesiadkowych w transporcie pasażerskim na przykładzie miasta Sosnowiec (Polska).

Słowa kluczowe: węzły przesiadkowe, transport, transport drogowy.

\section{Introduction}

Traveling is an important part of the daily activity of every human being. Transportation needs are usually secondary needs, resulting from the desire or need to go to study, work, medical care, public institutions and many other places. Each

\footnotetext{
${ }^{1}$ Graduate, Silesian University of Technology, Faculty of Transport and Aviation Engineering, Department of Transport Systems, Traffic Engineering and Logistics, email: angelanowak0097@gmail.com

2 PhD, DSc, Eng., Prof. SUT, Silesian University of Technology, Faculty of Transport and Aviation Engineering, email: elzbieta.macioszek@polsl.pl
} 
traveler is faced with the decision what means of transport he will use to reach the destination, whether they will be individual means of transport, such as a bicycle, private car or motorcycle, or will use the offer of public transport, shared mobility means or other means of transport available in the city, or it will combine both or some of this possibilities. The traveler, changing the mode of transport to another, for example, changing from bus to train, uses a transfer node. According to the definition $[1,2]$, a interchange node is a place in the transport system in which during the journey it is possible to change between at least two means of transport. The interchange node should be characterized by an appropriate level of transport accessibility, which can be improved with the use of ITS tools $[3,4]$. The construction of a interchange node in a given area should lead to favorable changes in the modal division, towards a greater share of travel with the use of public transport, while reducing the share of individual transport in road traffic.

Integrated interchange nodes, on the other hand, play an important role in the public transport system, at different levels of provided connections, from local or regional transport through national and international transport. Accurate layout and design of interchange nodes facilitates the use of various means of public transport, which in turn gives passengers the opportunity to reduce travel time and reduce the effort required to transfer between different means of transport. Transfer nodes, designed in a passenger-friendly manner, increase the satisfaction of users, which allows them to decide in the future on further journeys by means of public transport. Interchange nodes designed in a passenger-friendly manner enable their use not only by regular users, but also readable for those traveling for the first time in a given area (e.g. tourists), have an information function about current routes and departure times for public means of public transport, are located in a safe place, they are well lit and clean, and are accessible to all users, including the disabled people. The presence of the above-mentioned elements of the interchange nodes is the criterion for assessing the quality of the interchange. The most important characteristics of an interchange node that determine the quality are safety, cleanliness and transfer comfort [2]. In turn, the size of a interchange node and its area in the field depends on the number of communication lines serving a given interchange node and the frequency of their running, as well as the size of passenger traffic. The size of the interchange node increases with the increase of the above factors, which may adversely affect the orientation of passengers within the interchange and the distance between individual stops. Providing quick transfers with a short passage between platforms, without obstacles and without limitation of platform visibility is an ideal solution for travelers [5]. It is recommended that passenger crossing distances between platforms should not exceed $180 \mathrm{~m}$. Recommended crossing lengths between transfers are $30 \mathrm{~m}$ for a bus-tram junction; $60 \mathrm{~m}$ for metro-bus-tram and $90 \mathrm{~m}$ for train-metro [2]. In fact, these rules were usually met at the nodes analyzed in the paper. The paper presents the characteristics of the infrastructure of interchange nodes in passenger transport on the example of the city of Sosnowiec (Poland).

\section{Infrastructure of transfer nodes}

In the city of Sosnowiec, analyzed in the article, there are four types of stops with different equipment. These are bus, tram and bicycle stops as well as railway platforms. The most important element of the stop infrastructure is a board with the 
timetable of the available means of transport, while additionally there may be such elements as bus shelters, variable message boards, benches, ticket machines, litter bins, bicycle racks, advertising display cabinets, etc.

The timetable is information for travelers about available means of transport, numbers of communication lines, directions of travel of these lines and hours of planned departures. All information that must be included in such a timetable is specified in the Regulation of the Minister of Transport and Construction of January 13, 2006 on the content, method and dates of publishing timetables and updating them, conditions for incurring costs related to publishing information on timetables and providing timetables to the public [6]. According to the aforementioned regulation [6], the most important information in the timetable is the name (number) of the communication line with the specification of the starting and final stop and at least one intermediate stop, the date from which the given timetable is valid, validity of the timetable, specific days, hours, minutes of arrival/departure means of transport and the frequency of their running. The standard timetable available is a paper timetable, placed in a special case behind the glass (Figure 1a).

a).

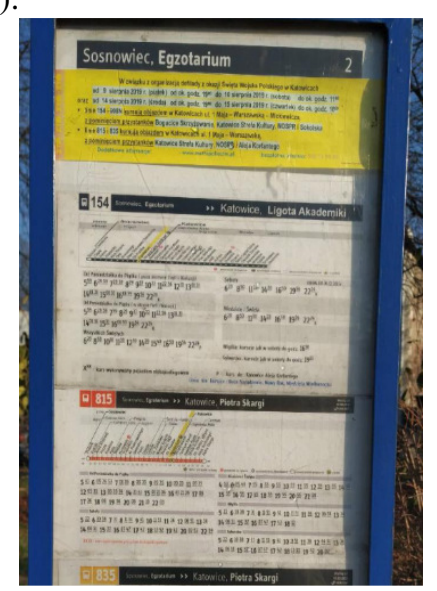

b).

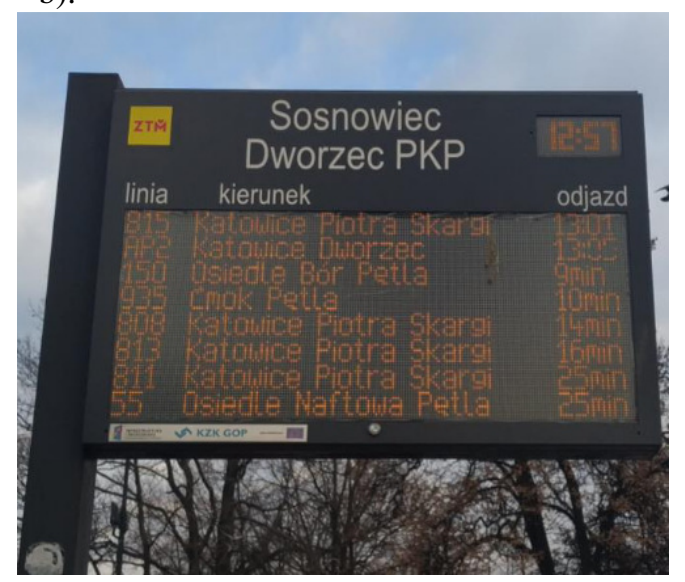

Figure 1. a). An example board with the timetable in the display case at the Sosnowiec Egzotarium bus stop, b). A variable message board at the Sosnowiec Dworzec PKP stop. Source: Own source.

On the other hand, the timetable in the form of a variable message board (Figure 1b) informs passengers about departures of communication lines, the direction of travel and the time of departure, taking into account the possible delay of the vehicle. Such boards are very often equipped with an additional button for the disabled (e.g. the blind), for whom the information displayed on the board could be read in the form of a voice message.

The bus stop shelters located within the stop are a place to wait for the means of public transport and are used to protect passengers against unfavorable weather conditions. The shelters are often equipped with benches, maps, lighting elements or advertising and advertising boards. The bus shelters are not closed spaces, they do not have four walls, usually there are shelters with three walls (Figure 2a), but they may not have them at all or have only one side wall (Figure 2b). Stop shelters are elements 
of the city's small architecture, which is why new shelters are created, which are not only useful but also affect the aesthetics of the city. Shelters without walls are used, among others, as roofing for bicycle rentals (Figure 2c). In order to promote a healthy lifestyle and cycling, cities also install special bicycle shelters (Figure 2d), most often located at transfer nodes, where people can leave their bike and continue your journey using public transport (Bike \& Ride system). The bus shelters can be made of steel, tempered glass as well as plastic. The size of a shelter depends on the volume of passenger traffic at a given stop in a transfer junction. The volume of passenger traffic determines the number of modules the carport consists of. On the Figure $2 \mathrm{e}$ an example of a four-module shelter is presented.

a).

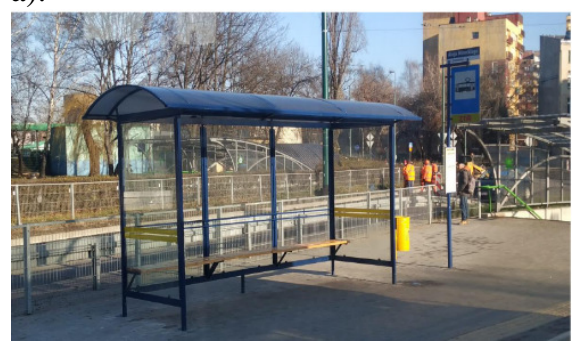

c).

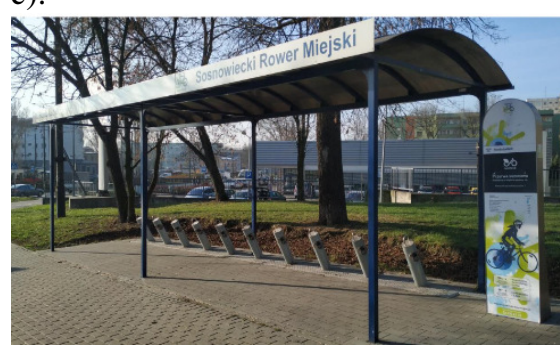

e).

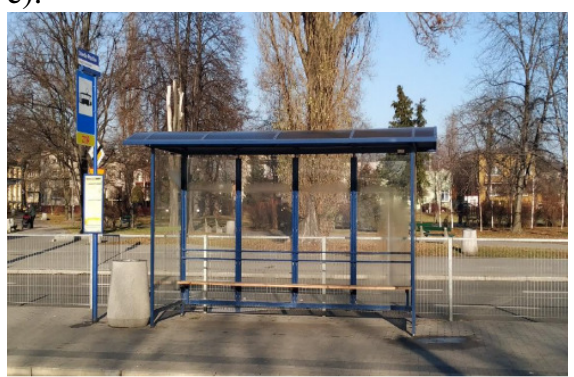

b).

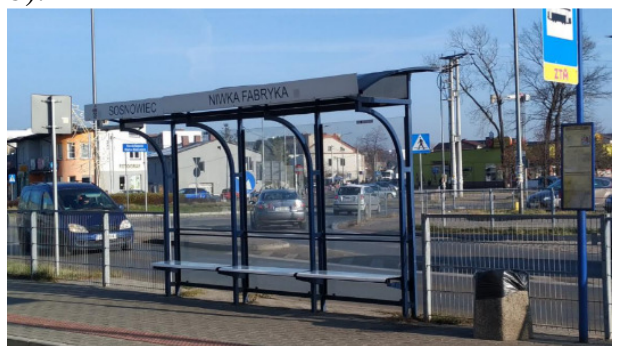

d).

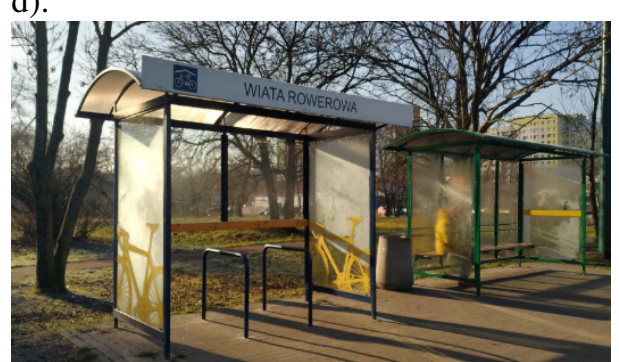

f).

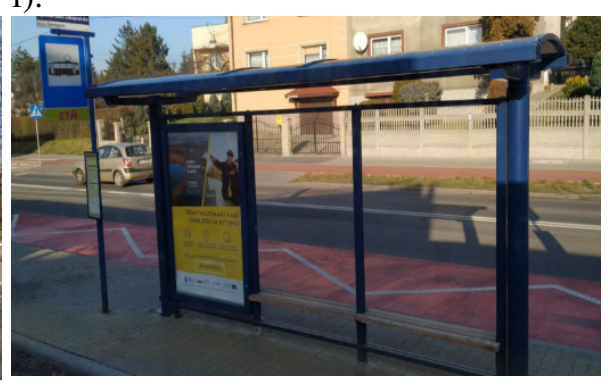

Figure 2. Bus shelter a). with three side walls at the stop Sosnowiec Aleja Mireckiego; $b$ ). with one side wall at the Sosnowiec Niwka Fabryka stop; c). Shelter without walls in the Sosnowiec transfer junction Rondo Ludwik; d). Bicycle shelter at the Sosnowiec Egzotarium stop; e). A four-module shelter at the Sosnowiec Osiedle Piastów stop; f). Two-sided shelter at the Sosnowiec Dębowa Góra Zakopiańska stop. Source: Own source. 
There are also two-sided shelters that are used at combined bus and tram stops. In places where the infrastructure, buildings and the location itself do not provide enough space for the installation of a separate shelter for a bus stop and a separate shelter for a tram stop, two-sided shelters are installed (Figure 2f).

\section{Characteristics of the research area}

Interchange nodes functioning in passenger transport were analyzed in the city of Sosnowiec in the Śląskie Voivodeship (Poland). The city belongs to the Metropolitan Area of Upper Silesia and Zagłębie (in Polish GZM), in which the Metropolitan Transport Authority is responsible for the organization of city transport. In the area of GZM there is a common transport price list, common ticket prices and the Silesian Public Services Card (in Polish ŚKUP). At the request of the Metropolitan Transport Authority, PKM Sosnowiec (in Polish Przedsiębiorstwo Komunikacji Miejskiej in Sosnowiec sp.z o.o.) and, to a small extent, PKM Jaworzno (in Polish Przedsiębiorstwo Komunikacji Miejskiej in Jaworzno) deals with the transport of people on public bus lines in Sosnowiec. On the other hand, the tram lines are transported by Tramwaje Śląskie S.A. There are a total of $333.5 \mathrm{~km}$ of roads in Sosnowiec, of which $12.0 \mathrm{~km}$ are national roads, $101.7 \mathrm{~km}$ are poviat roads and 219.8 $\mathrm{km}$ are municipal roads. The city is crossed by roads: $\mathrm{S} 1$ expressway, national road No. 1 (Cieszyn-Gdańsk), part of the European route E75, national road No. 86 (Wojkowice Kościelne-Będzin-Sosnowiec-Katowice-Tychy), national road No. 79 (Warsaw-Kraków-Bytom) ), national road No. 94 (Krzywa-Legnica-KatowiceKraków-Balice) and the A4 motorway.

In 2018 , about $8 \mathrm{~km}$ of bus lanes were created in the city. The solution was to reduce bus travel times through the city center. The length of the tram line network in Sosnowiec is $50,921 \mathrm{~km}$. This network connects the districts of: Dańdówka, Dębowa Góra, Kazimierz Górniczy, Klimontów, Milowice, Modrzejów, Niwka, Pogoń, Porąbka, Sielec, Stary Sosnowiec, Środula, Śródmieście and Zagórze. The current length of bicycle paths in Sosnowiec is just over $30 \mathrm{~km}$. There are 10 bike rental stations in the city, equipped with 130 bikes and operated by Nextbike Polska. The construction of further bicycle rentals is planned. Regional transport in Sosnowiec is performed by the following carriers: MAT-BUS, Kik-Bus Express, FlixBus, Kayatrans, DARJAN, Przedsiębiorstwo Przewozowe Łach Łukasz, OPARKA "DVL", PKS "K", "G", "M".

\section{Characteristics of interchanges nodes in the city of Sosnowiec}

A total of 41 interchange nodes were inventoried in the area of analysis. The most common are bus and tram nodes. There are also bus, tram and bicycle interchange nodes, bus-tram-train, train-bus-bicycle and tram-bicycle nodes (Figure 3). A list of all selected interchange nodes in the city of Sosnowiec is presented in Table 1. Additionally, Table 1 specifies means of transport available at the nodes.

As part of the work, the analysis covered all 41 interchange nodes located in the city of Sosnowiec. Due to the limitations of the article size, the article does not contain the characteristics of all interchange nodes. The characteristics of the infrastructure of one selected interchange node Sosnowiec Railway Station - 
Sosnowiec Główny were presented in the next subsection. This junction is the largest transfer junction in the city of Sosnowiec.

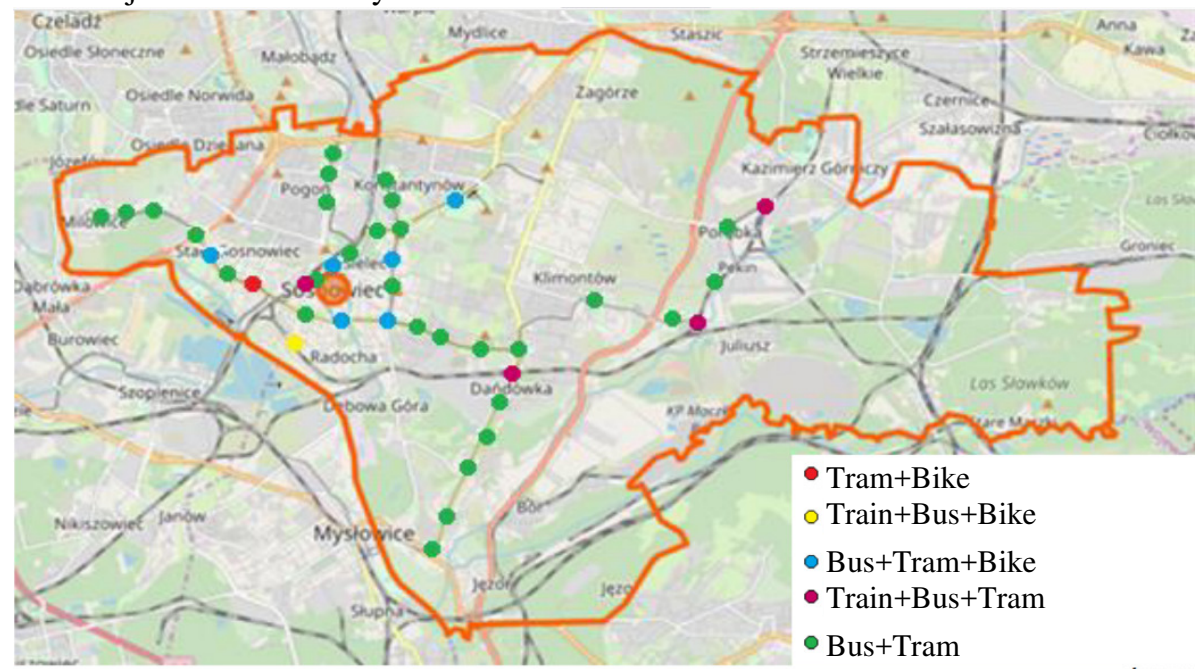

Figure 3. Location of interchange nodes in the city of Sosnowiec (Poland) Source: Own elaboration based on the Open Street Map [7]

Table 1. Transfer junctions in Sosnowiec with available means of transport

\begin{tabular}{|c|c|c|c|c|c|}
\hline \multirow[t]{2}{*}{ No. } & \multirow{2}{*}{ The name of the interchange node } & \multicolumn{4}{|c|}{ Mean of transport } \\
\hline & & Train & Bus & Tram & Bike \\
\hline 1. & Niwka Kościół & & $\mathrm{x}$ & $\mathrm{x}$ & \\
\hline 2. & Niwka Fabryka & & $\mathrm{x}$ & $\mathrm{x}$ & \\
\hline 3. & Niwka Pawiak & & $\mathrm{x}$ & $\mathrm{x}$ & \\
\hline 4. & Niwka Cmentarz Komunalny & & $\mathrm{x}$ & $\mathrm{x}$ & \\
\hline 5. & Dańdówka Osiedle & & $\mathrm{x}$ & $\mathrm{x}$ & \\
\hline 6. & Dańdówka Dworzec PKP - Sosnowiec Dańdówka & $\mathrm{x}$ & $\mathrm{x}$ & $\mathrm{x}$ & \\
\hline 7. & Dańdówka Skrzyżowanie & & $\mathrm{x}$ & $\mathrm{x}$ & \\
\hline 8. & Dańdówka Cmentarz & & $\mathrm{x}$ & $\mathrm{x}$ & \\
\hline 9. & Dębowa Góra Zakopiańska & & $\mathrm{x}$ & $\mathrm{x}$ & \\
\hline 10. & Sosnowiec Osiedle Wanda & & $\mathrm{x}$ & $\mathrm{x}$ & \\
\hline 11. & Sosnowiec Rondo Ludwik & & $\mathrm{x}$ & $\mathrm{x}$ & $\mathrm{x}$ \\
\hline 12. & Sosnowiec Ostrogórska & & $\mathrm{x}$ & $\mathrm{x}$ & $\mathrm{x}$ \\
\hline 13. & Sosnowiec Wspólna & & $\mathrm{x}$ & $\mathrm{x}$ & \\
\hline 14. & Osiedle Naftowa - Sosnowiec Południowy & $\mathrm{x}$ & $\mathrm{x}$ & & $\mathrm{x}$ \\
\hline 15. & Sosnowiec Dworzec PKP - Sosnowiec Główny & $\mathrm{x}$ & $\mathrm{x}$ & $\mathrm{x}$ & \\
\hline 16. & Sosnowiec Aleja Mireckiego & & & $\mathrm{x}$ & $\mathrm{x}$ \\
\hline 17. & Sosnowiec Osiedle Piastów & & $\mathrm{x}$ & $\mathrm{x}$ & \\
\hline 18. & Sosnowiec Egzotarium & & $\mathrm{x}$ & $\mathrm{x}$ & $\mathrm{x}$ \\
\hline 19. & Milowice Park Logistyczny & & $\mathrm{x}$ & $\mathrm{x}$ & \\
\hline 20. & Milowice Podjazdowa & & $\mathrm{x}$ & $\mathrm{x}$ & \\
\hline 21. & Milowice Zakłady Mięsne & & $\mathrm{x}$ & $\mathrm{x}$ & \\
\hline 22. & Milowice Hala Sportowa & & $\mathrm{x}$ & $\mathrm{x}$ & \\
\hline 23. & Sosnowiec Aleja Zwycięstwa & & $\mathrm{x}$ & $\mathrm{x}$ & \\
\hline 24. & Sosnowiec Estakada & & $\mathrm{x}$ & $\mathrm{x}$ & $\mathrm{x}$ \\
\hline 25. & Siedlec Park & & $\mathrm{x}$ & $\mathrm{x}$ & \\
\hline
\end{tabular}




\begin{tabular}{|c|c|c|c|c|c|}
\hline 26. & Siedlec Kąpielisko & & $\mathrm{X}$ & $\mathrm{X}$ & \\
\hline 27. & Siedlec Osiedle Zamkowa & & $\mathrm{x}$ & $\mathrm{x}$ & \\
\hline 28. & Siedlec Szkolna & & $\mathrm{x}$ & $\mathrm{x}$ & $\mathrm{x}$ \\
\hline 29. & Siedlec Narutowicza & & $\mathrm{x}$ & $\mathrm{x}$ & \\
\hline 30. & Środula Osiedle & & $\mathrm{x}$ & $\mathrm{x}$ & $\mathrm{x}$ \\
\hline 31. & Konstantynów Fabryczna & & $\mathrm{x}$ & $\mathrm{x}$ & \\
\hline 32. & Konstantynów Okrzei & & $\mathrm{x}$ & $\mathrm{x}$ & \\
\hline 33. & Pogoń Kościół & & $\mathrm{x}$ & $\mathrm{x}$ & \\
\hline 34. & Pogoń Rybna & & $\mathrm{x}$ & $\mathrm{x}$ & \\
\hline 35. & Pogoń Akademiki & & $\mathrm{x}$ & $\mathrm{x}$ & \\
\hline 36. & Klimontów Basen & & $\mathrm{x}$ & $\mathrm{x}$ & \\
\hline 37. & Klimontów Hospicjum & & $\mathrm{x}$ & $\mathrm{x}$ & \\
\hline 38. & Porąbka Dworzec PKP - Sosnowiec Porąbka & $\mathrm{x}$ & $\mathrm{x}$ & $\mathrm{x}$ & \\
\hline 39. & Porąbka Łukasiewicza & & $\mathrm{x}$ & $\mathrm{x}$ & \\
\hline 40. & Porąbka Wiejska & & $\mathrm{x}$ & $\mathrm{x}$ & \\
\hline 41. & Kazimierz Górniczy Pętla - Sosnowiec Kazimierz & $\mathrm{x}$ & $\mathrm{x}$ & $\mathrm{x}$ & \\
\hline
\end{tabular}

Source: Own research.

\subsection{Characteristics of the Sosnowiec interchange node Railway Station - Sosnowiec Główny}

Sosnowiec interchange node Railway Station - Sosnowiec Główny is the largest interchange node located in the city center, enabling the change of means of transport between train, bus and tram. High traffic volume of buses resulted in the division of one of the bus stops in the node into two separate A1 and A2 (Figure 4), which in practice allows for the simultaneous operation of several buses at the same time. The directions of travel and the corresponding numbers of communication lines at the A1 bus stop are shown in Table 2, and for the A2 stop in Table 3.

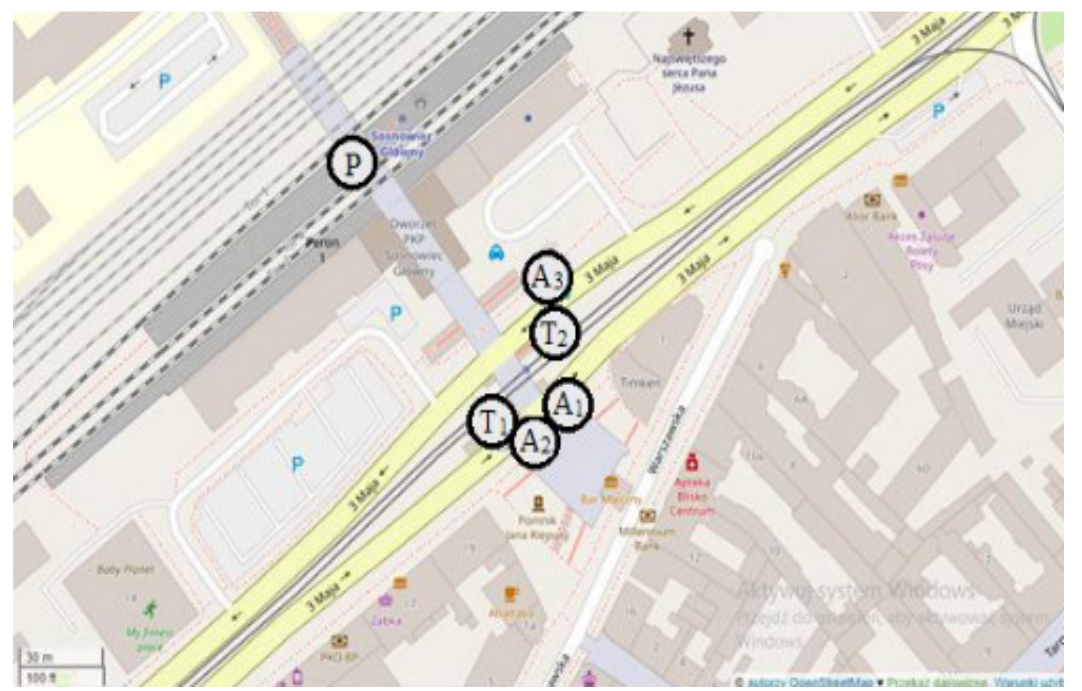

Figure 4. Interchange node Sosnowiec Railway Station - Sosnowiec Główny. Where: A1 - bus stop, A2 - bus stop, T1 - tram stop, T2 - tram stop, $P$ - train station Source: Own research based on the Open Street Map [7] 
Table 2. Driving directions and corresponding line numbers at the Sosnowiec Railway Station Al stop

\begin{tabular}{|c|c|c|}
\hline The name of the carrier & Line number & Direction \\
\hline \multirow[t]{10}{*}{ ZTM } & 26 & Sosnowiec Szpital Wojewódzki \\
\hline & 35 & Wojkowice Park \\
\hline & 91 & Sosnowiec Urząd Miasta \\
\hline & 100 & Wojkowice Park \\
\hline & 150 & Sosnowiec Szpital Wojewódzki \\
\hline & 188 & Sosnowiec Szpital Wojewódzki \\
\hline & 813 & Katowice Piotra Skargi \\
\hline & $908 \mathrm{~N}$ & Sosnowiec Urząd Miasta \\
\hline & 935 & Czeladź Wojkowicka Pętla \\
\hline & $\mathrm{AP} 2$ & Pyrzowice Port Lotniczy \\
\hline PKM Jaworzno & $\mathrm{S}$ & Sosnowiec Szpital Wojewódzki \\
\hline \multicolumn{2}{|l|}{ Kayatrans } & Kraków Dworzec PKS \\
\hline \multirow[t]{4}{*}{ Fixbus } & & Kraków Dworzec PKS \\
\hline & & Częstochowa \\
\hline & & Łodź \\
\hline & & Warszawa \\
\hline Kik-Bus Express & & Olkusz \\
\hline \multirow[t]{3}{*}{ ŁŁ Bus } & & Busko Zdrój \\
\hline & & Kielce \\
\hline & & Włoszczowa \\
\hline \multirow[t]{2}{*}{ Mat Bus } & & Busko Zdrój \\
\hline & & Chmielnik \\
\hline OPARKA DVL & & Kielce \\
\hline
\end{tabular}

Source: Own research.

Table 3. Driving directions and corresponding line numbers at the Sosnowiec Railway Station A2 stop

\begin{tabular}{|l|l|l|}
\hline The name of the carrier & \multicolumn{1}{|c|}{ Line number } & \multicolumn{1}{c|}{ Direction } \\
\hline ZTM & 55 & Gołonóg Zajezdnia \\
\cline { 2 - 3 } & 106 & Zagórze Zajezdnia \\
\cline { 2 - 3 } & 160 & Sosnowiec Urząd Miasta \\
\cline { 2 - 3 } & $160 \mathrm{~S}$ & Sosnowiec Urząd Miasta \\
\cline { 2 - 3 } & 299 & Zagórze Zajezdnia \\
\cline { 2 - 3 } & 690 & Gołonóg Zajezdnia \\
\cline { 2 - 3 } & 723 & Zagórze Zajezdnia \\
\cline { 2 - 3 } & 808 & Tworzeń Huta Katowice \\
\cline { 2 - 3 } & 811 & Tworzeń Huta Katowice \\
\cline { 2 - 3 } & 815 & Ostrowy Górnicze Pomnik \\
\cline { 2 - 3 } & $902 \mathrm{~N}$ & Sosnowiec Urząd Miasta \\
\hline
\end{tabular}

Source: Own research.

Bus lines serving the A3 bus stop and their directions are presented in Table 4. The numbers of lines and their directions of travel for the T1 tram stop are presented in Table 5 and for the T2 direction in Table 6. 
Table 4. Driving directions and corresponding line numbers at the Sosnowiec Railway Station A3 stop

\begin{tabular}{|l|l|l|}
\hline \multicolumn{1}{|c|}{ The name of the carrier } & \multicolumn{1}{|c|}{ Line number } & \multicolumn{1}{c|}{ Direction } \\
\hline \multirow{5}{*}{ ZTM } & 26 & Jęzor Centrum Handlowe \\
\cline { 2 - 3 } & 36 & Mysłowice Kosztowy Pętla \\
\cline { 2 - 3 } & 55 & Osiedle Naftowa Pętla \\
\cline { 2 - 3 } & 106 & Mysłowice Brzezinka Pętla \\
\cline { 2 - 3 } & 150 & Osiedle Bór Pętla \\
\cline { 2 - 3 } & $160 \mathrm{~S}$ & Bobrek Inwestycyjna Pętla II \\
\cline { 2 - 3 } & 299 & Sosnowiec Szpital Wojewódzki \\
\cline { 2 - 3 } & 723 & Czeladź Wojkowicka Pętla \\
\cline { 2 - 3 } & 808 & Katowice Piotra Skargi \\
\cline { 2 - 3 } & 811 & Katowice Piotra Skargi \\
\cline { 2 - 3 } & 813 & Katowice Piotra Skargi \\
\cline { 2 - 3 } & 815 & Katowice Piotra Skargi \\
\cline { 2 - 3 } & $908 \mathrm{~N}$ & Katowice Dworzec \\
\cline { 2 - 3 } & 935 & Mysłowice Ćmok Pętla \\
\cline { 2 - 3 } & AP2 & Katowice Dworzec \\
\hline PKM Jaworzno & $\mathrm{S}$ & Jaworzno Krakowska Pętla \\
\hline Kik-Bus Express & Katowice Dworzec PKS \\
\hline ŁŁ Bus & Katowice Dworzec PKS \\
\hline Mat-Bus & Katowice Dworzec PKS \\
\hline Zebra Bus & Kraków \\
\cline { 2 - 3 } & Zakopane \\
\hline
\end{tabular}

Source: Own research.

Table 5. Driving directions and corresponding tram line numbers at the Sosnowiec Railway Station T1 stop

\begin{tabular}{|c|c|}
\hline Line number & Direction \\
\hline 15 & Sosnowiec Zagórze Pętla \\
\hline 21 & Gołonóg Podstacja Pętla \\
\hline 26 & Będzin Osiedle Zamkowe Pętla \\
\hline
\end{tabular}

Source: Own research.

Table 6. Driving directions and corresponding tram line numbers at the Sosnowiec Railway Station T2 stop

\begin{tabular}{|c|c|}
\hline Line number & Direction \\
\hline 15 & Katowice Plac Wolności \\
\hline 21 & Milowice Pętla \\
\hline 24 & Konstantynów Okrzei \\
\hline 26 & Milowice Pętla \\
\hline 27 & Kazimierz Górniczy Pętla \\
\hline
\end{tabular}

Source: Own research. 
In turn, Table 7 presents the relations of trains stopping at the Sosnowiec Główny railway station (marked on the map with the letter P - Figure 4). The infrastructure of the stops at the Sosnowiec Railway Station - Sosnowiec Główny intersection node is shown in Table 8. It provides information on the number of infrastructure elements present at individual stops.

Table 7. Train relations at the Sosnowiec Główny Railway Station

\begin{tabular}{|c|c|}
\hline The name of the carrier & Relation \\
\hline \multirow[t]{16}{*}{ PKP INTERCITY } & Gdynia Główna - Katowice \\
\hline & Gdynia Główna - Wiedeń \\
\hline & Gdynia Główna - Bielsko Biała Główna \\
\hline & Gdynia Główna - Gliwice \\
\hline & Budapeszt - Brest \\
\hline & Praga - Terespol \\
\hline & Praga - Moskwa \\
\hline & Lublin Główny - Wrocław Główny \\
\hline & Szczecin Główny - Lublin Główny \\
\hline & Warszawa Wschodnia - Praga \\
\hline & Warszawa Wschodnia - Wiedeń \\
\hline & Warszawa Wschodnia - Racibórz \\
\hline & Warszawa Wschodnia - Ostrawa \\
\hline & Warszawa Wschodnia - Zakopane \\
\hline & Warszawa Wschodnia - Gliwice \\
\hline & Warszawa Wschodnia - Bielsko Biała \\
\hline \multirow[t]{7}{*}{ KOLEJE ŚLĄSKIE } & Gliwice - Częstochowa \\
\hline & Gliwice - Zawiercie \\
\hline & Dąbrowa Górnicza Ząbkowice - Gliwice \\
\hline & Sosnowiec Główny - Tychy Lodowisko \\
\hline & Wisła Głębce - Częstochowa \\
\hline & Żywiec - Częstochowa \\
\hline & Zwardoń - Zawiercie \\
\hline PRZEWOZY REGIONALNE & Kielce - Katowice \\
\hline
\end{tabular}

Source: Own research.

Table 8. Infrastructure of the intersection node Sosnowiec Railway Station Sosnowiec Główny

\begin{tabular}{|c|c|c|c|c|c|c|c|}
\hline Stop & $\begin{array}{c}\text { The } \\
\text { carport }\end{array}$ & Timetable & $\begin{array}{c}\text { ŚKUP } \\
\text { machine }\end{array}$ & Bench & $\begin{array}{c}\text { Trash } \\
\text { can }\end{array}$ & $\begin{array}{c}\text { Bicycle } \\
\text { stand }\end{array}$ & $\begin{array}{c}\text { Advertisement } \\
\text { display } \\
\text { cabinet }\end{array}$ \\
\hline $\mathbf{A}_{\mathbf{1}}$ & 1 & 1 & - & 2 & 2 & - & - \\
\hline $\mathbf{A}_{\mathbf{2}}$ & 1 & 1 & 1 & 2 & 2 & - & - \\
\hline $\mathbf{A}_{\mathbf{3}}$ & 1 & 2 & 1 & 3 & 4 & - & 1 \\
\hline $\mathbf{T}_{\mathbf{1}}$ & 1 & 1 & - & 1 & 2 & - & - \\
\hline $\mathbf{T}_{\mathbf{2}}$ & 1 & 1 & - & 1 & 2 & - & - \\
\hline $\mathbf{P}$ & 1 & 2 & - & 16 & 8 & - & 2 \\
\hline
\end{tabular}

Source: Own research. 


\section{Conclusions}

Each interchange node plays an important role in the city's public transport. Interchange nodes allow travelers to choose the means of transport and make it possible to change it. After a thorough analysis of the interchange nodes in Sosnowiec (Poland), it can be seen that $97 \%$ of them are located along the city's tram lines. Only one of the analyzed junctions (Osiedle Naftowa-Sosnowiec Południowy) does not allow changing the mode of transport to a tram. Such an arrangement of interchange nodes by tram lines allows passengers to change quickly when the bus is in a traffic jam (the tram does not have this problem while driving along its tracks). Moreover, in Sosnowiec, actions are being taken to make it easier for passengers to change the means of transport, hence new junctions have been built and some of the existing ones have been rebuilt in such a way that people with disabilities or traveling with a pram can easily move from one place to another one. For this purpose, ramps or elevators are built. Additional footbridges are also being built, including those designed specifically for bicycle traffic.

Every stop at the interchange node is provided with a timetable. The remaining elements of the infrastructure vary depending on the location of the interchange node and the individual stops. There are stops with interconnected infrastructure, which are usually located in places with limited space. Interchange nodes consisting of six or more stops are usually best equipped, each stop has a timetable, a shelter, a bench and a garbage can. Poorly equipped stops are usually served by one or two communication lines, which does not make them attractive interchanges. The city's largest transport hub is Sosnowiec Railway Station. It is used by the largest number of bus lines, all city tram lines and numerous trains. The node is equipped with all possible infrastructure elements with an additional elevator for disabled people and is a passenger-friendly node. The distances between the stops are as short as possible, the information about bus departures displayed on the passenger information boards is legible and up-to-date.

New bicycle paths and bicycle rental stations are being built in the city of Sosnowiec. The Bike \& Ride system is being introduced in the city - this is evidenced by the observed bicycle shelters located at the interchange nodes. All this increases the attractiveness of bicycle transport in the city.

\section{REFERENCES}

1. MONIGL J., BERKI Z., SZEKELY A.: NICHES+ Guidelines for implementers of Passenger Friendly Interchanges, 2010.

2. SZYMAŃSKI W.: Szwajcarskie standardy dla węzłów przesiadkowych. Zielone Mazowsze. Available at: http://www.zm.org.pl/?a=szwajcaria-094.

3. LACH D., MACIOSZEK E.: Analiza wybranych usług ITS wykorzystywanych w publicznym transporcie zbiorowym. Prace Naukowe Politechniki Warszawskiej. Seria Transport z. 121. Problemy Transportu w Inżynierii Logistyki - część 4. str. 211-222. Oficyna Wydawnicza Politechniki Warszawskiej. Warszawa 2018.

4. KUREK A., MACIOSZEK E., ŚWIERK P.: Narzędzie ITS wspomagające zarządzanie informacją o ruchu w mieście - studium przypadku na przykładzie miasta dużej wielkości zlokalizowanego w Polsce, [w:] Galińska B. (red.): Współczesne aspekty zarządzania logistyką. Monografie Politechniki Łódzkiej, Łódź 2019, s. 79-96. 
5. OLSZEWSKI P., KRUKOWSKA H., KRUKOWSKI P.: Metodyka oceny wskaźnikowej węzłów przesiadkowych transportu publicznego. Transport Miejski i Regionalny 2014, vol. 6, pp. 4-9.

6. USTAWA z dnia 13 stycznia 2006r. w sprawie treści, sposobu i terminów ogłaszania rozkładów jazdy oraz ich aktualizacji, warunków ponoszenia kosztów związanych z zamieszczaniem informacji dotyczących rozkładów jazdy oraz podawaniem rozkładów jazdy do publicznej wiadomości. (Dz. U. Nr 50, poz. 601).

7. OPEN STREET MAP. Available at: https://www.openstreetmap.org/. 